\title{
ENERGIZING COMMUNITIES THROUGH PARTNERSHIPS WITH EXTERNAL ACTORS: SMALL-SCALE HYDROPOWER PROJECTS IN JAPAN
}

\author{
Yasuko Honda \\ Department of Rural Environment Management, Graduate School of Environmental and Life \\ Science, Okayama University, Japan. \\ E-mail: yhonda@okayama-u.ac.jp
}

Citation: Honda, Y., 2021. Energizing Communities through Partnerships with External Actors: Small-Scale Hydropower Projects in Japan. J. Asian Rur. Stud. 5(1): 63-77

\begin{abstract}
This study aims to specify the contextual conditions that allow for the success of community renewable energy projects, against the background of the expanding use of renewable energy. It analyzes cases where farmers invested in organizations to establish ownership of hydropower plants in the Chugoku region, Japan. Community renewable energy projects derived from local initiatives to provide an alternative energy resource and serve as a catalyst for rural development. However, the costs of small hydropower plant construction and the expert knowledge required for their operation could hinder the diffusion of the technology. Population decline and aging in rural communities also constrain the development of community renewable energy projects. This study presents cases that illuminate the conditions enabling these organizations to succeed in securing the necessary resources for the operation of their renewable energy plants. The survey illustrates how studied organizations have opted to collaborate with external actors to construct or refurbish their plants. The findings indicate that as building partnerships with external actors often becomes essential, it is vital to develop a business-minded framework in which both communities and external actors can financially benefit from introducing small hydropower projects. The cases also reveal that in building collaborative relationships, broad disparities exist between communities and external actors in financial power and expert knowledge, which give the latter substantial advantages in negotiations. An additional important claim derived is that, for an effective partnership that enables a successful community renewable energy project, a third party with expert knowledge and the ability to audit partnershipbuilding processes could play a crucial role in securing community initiatives and independence.
\end{abstract}

Keywords: Community renewable energy; rural community; local initiative; Japan Agricultural Cooperatives; energy cooperative

\section{Introduction}

The use of renewable energy to help prevent climate change and reduce air pollution is expanding because of its environmentally benign nature and cost benefits. Simultaneously, rural development through renewable energy projects established by local communities, such as community energy (Walker et al., 2007; Brummer, 2008) or community renewable energy projects (Walker and Devine-Wright, 2008; Kaphengst and Velten, 2014), is also expanding. Renewable energy can have socioeconomic benefits for rural areas, including income generation, job creation, and positive tourism and education 
outcomes. Moreover, community-led renewable energy, unlike large business-led initiatives, can promote local knowledge and networks, and strengthen local territorial resource management initiatives (Hinshelwood, 2001).

Among the different types of commercial renewable energy, hydroelectric power was introduced relatively early in the late 19th century, in contrast to solar power, which was first implemented in the 1950s. Small-scale hydroelectric power (small hydropower) that does not require large-scale dam development is now gaining more attention. In Japan, over $70 \%$ of hydropower plants produce $10 \mathrm{MW}$ or less. Although there is no internationally agreed definition, hydropower of up to $10 \mathrm{MW}$ is generally classified as small hydropower (Paish, 2002). In Japan's 1997 New Energy Law, hydropower of up to $1 \mathrm{MW}$ is defined as small hydropower (Law Concerning Special Measures to Promote the Use of New Energy).

Studies on renewable energy in EU countries have mainly focused on wind power generation (e.g., Schreuer and Weismeire-Sammer, 2010), although Bracken et al. (2014) reported the expanding use of small hydropower by local communities in the UK. In developing countries, small hydropower has the potential to improve lives in rural areas where electricity is unavailable (e.g., Ahlborg and Sjöstedt, 2015). For example, the Indian government has introduced small hydropower to improve the lives of farmers in the Himalayan and sub-Himalayan regions (Reddy et al., 2006). Reddy et al. (2006) indicated that the critical factors to consider when developing continuing power generation include whether the local community can maintain and repair the power generation facilities. Reddy et al. (2006) also mentioned that a good relationship can be established with other stakeholders, such as business operators and public administrations, and that local communities can have a sense of ownership. Thus, importantly, studies on community-based small hydropower projects highlighted community initiatives and external actors' support.

The present study focused on small hydropower plants constructed by Japan Agricultural Cooperatives (JACs) in the Chugoku region, which have been maintained by local communities for the last 60 to 70 years. The Agricultural Cooperative Law of 1947 established JACs after World War II. JACs engage in various business activities for farmers, primarily marketing their products and providing financing. Although they have been the driving force behind farmer-supportive policies and have demonstrated their economic, social, and political power through the early 1990s, the conversion to proliberalization policies from the mid-1990s has pressed them to streamline their businesses (Fabusoro et al., 2012). Generally, farmers participate in JACs within their respective areas. There were 607 agricultural cooperatives and 10.51 million members at the end of FY2017 (National Federation of Agricultural Cooperative Association, 2019).

Japan benefits from steep terrain and abundant water resources, making it suitable for hydropower. However, given the regional monopoly of energy supply, 10 privately owned electric power companies have taken control of a large portion of Japan's energy supply. Nevertheless, JACs constructed many small hydropower plants, specifically in the Chugoku region during the 1950s and the 1960s, and today, about 50 plants remain in operation. This region's small hydropower plants developed through local initiatives are excellent examples of community renewable energy. However, studies on renewable energy in Japan have frequently focused on the drastic changes in energy and climate policy after the Fukushima nuclear power plant accident (e.g., Mizuno, 2014; Kuramochi, 
2015). Although policy measures are indeed essential to promote energy transition, the community-based forms of renewable energy production and management should also be considered.

Therefore, this study focuses on these plants because of the lack of empirical studies on community energy projects in Japan. This study intends to specify the contextual conditions of community renewable energy projects in the Chugoku region, Japan. Specifically, we examine the relationship between rural communities and external actors in community-based renewable energy and the role of these external actors. Communitybased forms of renewable energy production vary by country or region depending on various socioeconomic contexts. By illustrating, one approach to community renewable energy in a specific context, this study may provide primary data that can be utilized to develop a comparison with community renewable energy projects in European or developing countries.

The next section in this study provides an explanation of the methodologies and study area. The third section describes the characteristics of small hydropower plants in the Chugoku region and why the local communities able to construct small hydropower plants in the 1950s and 1960s. It also assesses the Japan Agricultural Cooperatives for Electrification (JACEs). As described below, JACEs owned by local communities and are similar to green energy cooperatives. In this section, vital and informative interviews illuminate the challenges JACEs face to raise funds, to collaborate with external actors to refurbish their plants in recent years. Finally, consideration of the findings from the two time periods will yield more general conclusions that can enable local communities to keep their initiatives in governing community renewable energy projects.

\section{Materials and Methods}

\subsection{Methods}

The data used in this study were obtained by non-anonymous, face-to-face interviews with key informants from May 2014 to November 2017, and secondary data included statistical materials, published documents, and other administrative documents. There were 28 owners of small hydropower plants in the Chugoku region as of October 2016 (see below). Of these owners, firstly, semi-structured interviews with the representatives of nine operating organizations (two JACs, four JACEs, two Land Improvement Districts, and one local municipality). Land Improvement Districts formally reorganized the prewar irrigation water user associations based on the Land Improvement Law enacted in 1949 (Sarker, 2014). An interview with the secretariat of the Chugoku Small Hydropower Association because all small hydropower plant owners in the region participate in the association. Second, detailed interviews with the presidents of four JACEs (A, B, C, D) in Tottori Prefecture and the last president of the Tottori Small Hydropower Association (TSHA) who supported JACE-A (see Section 3.3.2.2.). All small hydropower plant owners in Tottori prefecture, including the four JACEs, participate in TSHA. Interviews also conducted with a former secretary to the late Mr. Shiro Oda. He was the leader of the community-led small hydropower development movement in the 1950s and the 1960s (see Section 3.2). All interviews recorded and transcribed. 


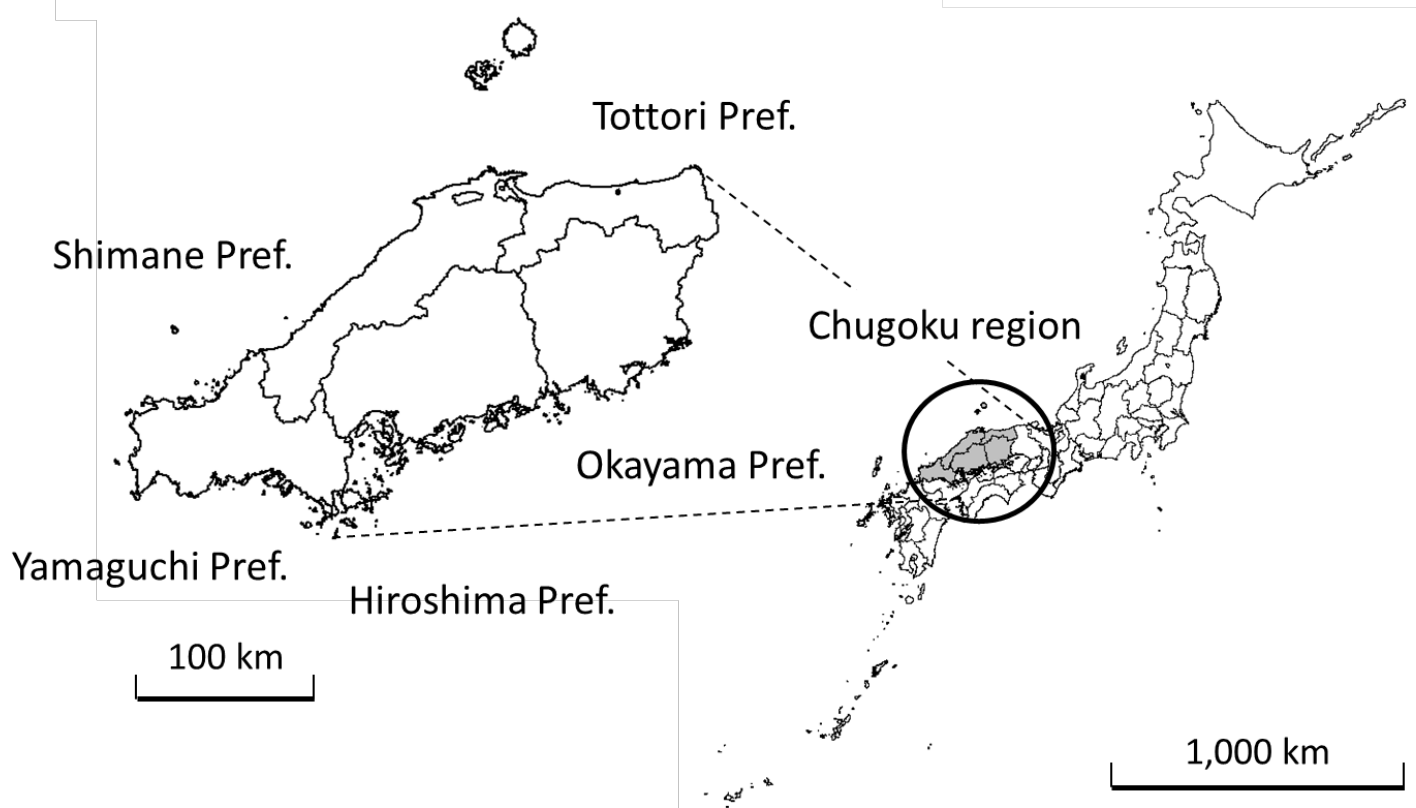

Figure 1. Location of study area

\subsection{Study Area: The Chugoku Region}

The Chugoku region, located in the western part of Japan's main island (Figure 1), has an area of $31,922 \mathrm{~km}^{2}$ and approximately 7.4 million people, as of 2015 . Gently sloping mountains with lower altitudes, between 1,000 and 1,300 meters above sea level, lie to the east and west of this region. Mountainous and hilly areas account for $88 \%$ of the total area, compared to the national average of $73 \%$. The ratio of inhabited to entire land area is $64 \%$, ranked second behind the Tokyo metropolitan area (67\%), and significantly higher than the national average of $48 \%$. The data indicate that the hilly and the mountainous regions of Chugoku are more extensively inhabited than other parts of Japan.

The Chugoku region comprises five prefectures: Tottori, Shimane, Okayama, Hiroshima, and Yamaguchi. Hiroshima city, the capital of Hiroshima Prefecture, is the largest city in the region, with over one million people. While the manufacturing industry prospered in the coastal areas along the Seto Inland Sea (the southern part of Okayama, Hiroshima, and Yamaguchi prefectures), the mountainous regions, particularly those in Tottori and Shimane prefectures, have a significant agricultural disadvantage due to small, scattered, and mountainous farmlands. Hence, against the background of Japan's population decline, the latter areas have experienced more rapid depopulation and an aging society. Although mountainous areas in the region have many environmental values, such as attractive landscapes and local ecosystems, tourist activities have a relatively low presence. Thus, the eco-economic paradox mentioned by Kitchen and Marsden (2009), i.e., the higher the environmental value of rural areas, the lower the economic activities in these areas, applies in this case. It is considered that this region, particularly its mountainous areas, requires a new approach to rural development to prevent depopulation and aging and stimulate the local economy. 


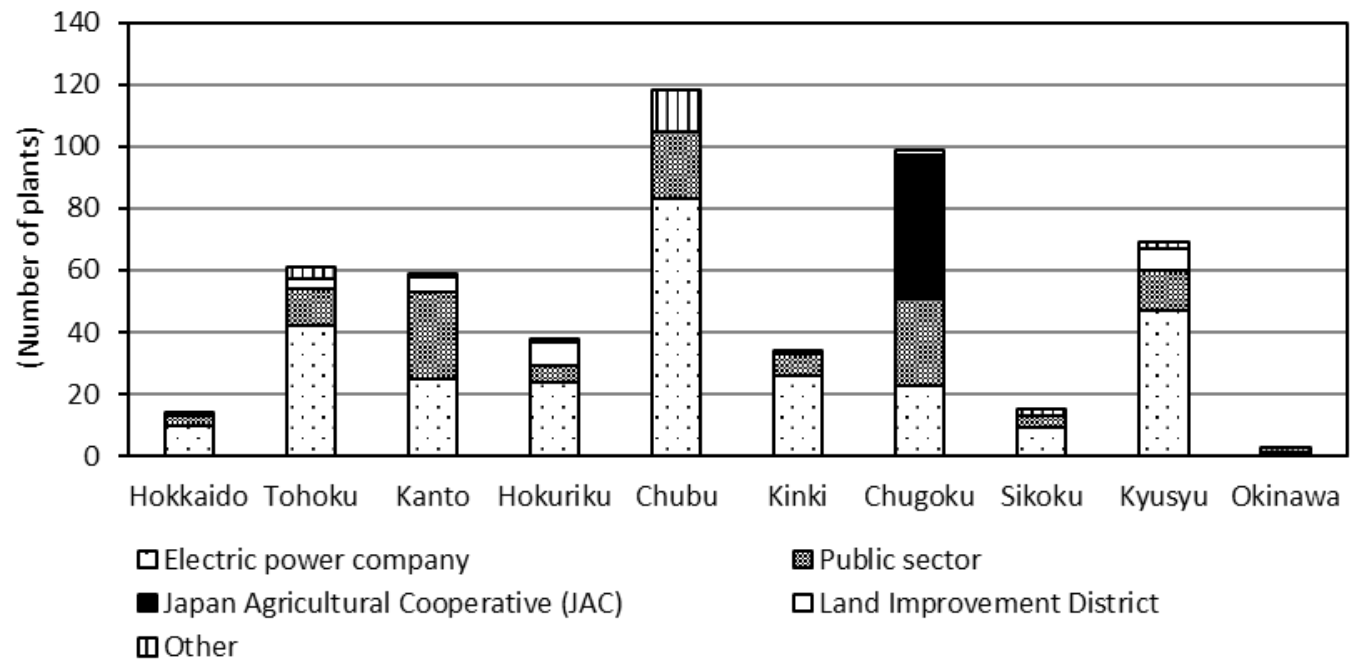

Figure 2. Number of small hydropower plants and their owners by region.

Source: Agency for Natural Resources and Energy (2012)

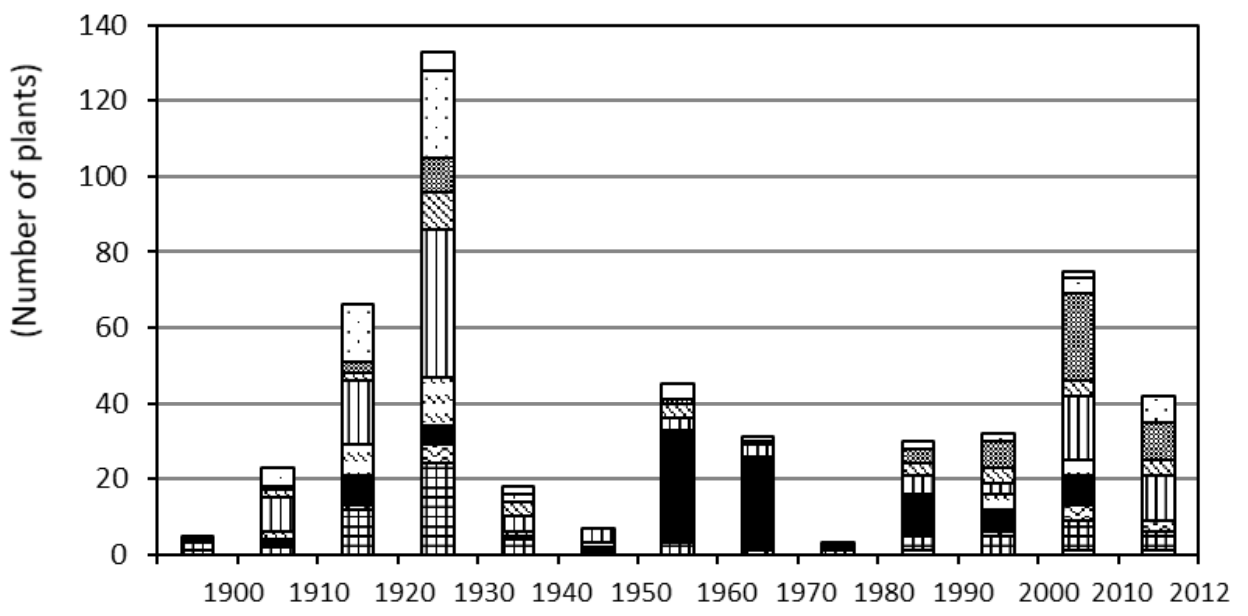

$\square$ Hokkaido

口Tohoku

圆 Kanto

SHokuriku

mChubu

○ Kinki

Chugoku

曰Shikoku

田 Kyushu

曰Okinawa

Figure 3. Number of small hydropower plants established by region.

(Year)

Source: Agency for Natural Resources and Energy (2012)

\section{Results and Discussion}

\subsection{Development of Community-Based Small Hydropower Projects in Chugoku Region}

There were 510 small hydropower plants in Japan at the end of March 2012; Chugoku regions' 99 plants (19\%) came second to Chubu region's 118 plants (23\%) (Figure 2).

Small hydropower plants in the Chugoku region have two characteristics. First, more than half of the plants constructed in the 1950s and 1960s in the Chugoku region, while a quarter of small hydropower plants erected in the 1920s, and the final quarter were built after 2000 throughout Japan (Figure 3). Second, about half of the plants owned by JACs in the Chugoku region, while the electric power companies own the remainder of plants in Japan (Figure 2). As mentioned, the 10 large, privately owned electric power companies dominated and controlled the energy market in their respective service areas (Figures 2 and 3). Moreover, the operators of hydropower plants could not sell generated power directly to consumers; operators could sell only to the power company in the 
region. Therefore, the small hydropower plants' owners were divided into three groups: the electric power companies, including their associated companies; the public sector (e.g., national, prefectural or local governments, or companies controlled by these governments); and the private sector, except the electric power companies (e.g., JACs, Land Improvement Districts, or the others) (Figure 3).

This study focused on the plants constructed by JACs (except one plant constructed by a Land Improvement District) from the late 1940s to 1970 through the Act on the Promotion of Introducing Electricity into Farming and Fishing Villages (Section 3.2.). The plants were grid-connected rather than stand-alone facilities, so the electricity generated were sold to the electric power company in the region (Chugoku Electric Power Company). Local owners operate all plants, with profits returned to rural development (Section 3.2.). Additionally, all small hydropower owners have joined the Chugoku Small Hydropower Association.

Most small hydropower plants designed with the "run-of-the-river" system that requires little or no water storage facilities and diverts water using an open channel or pipes over long distances to take advantage of elevation changes, as well as allowing it to flow into a turbine via a pipeline. Most plants have purpose-built facilities and do not interfere with the current water usage, except a few plants, including those engaged by Land Improvement Districts that utilize irrigation water to generate electricity.

During construction, all the plants operated by local JACs. However, some hydropower plants were taken over by local communities, local municipalities, or Land Improvement Districts following management streamlining that merged the JACs. When a local community appropriated the operation of a plant, a JACE was established with investment from community residents. Small hydropower business operators (owners) of the Chugoku region currently classified into four groups: 14 JACs, operating 33 plants; 6 JACEs operating 1 plant each; 6 local municipalities (town or village offices) or a third sector (joint ventures of local municipality and JAC) operating 1 plant each; and 2 Land Improvement Districts operating 1 plant each.

\subsection{Community-Led Small Hydropower Movement in the 1950s and 1960s}

Small hydropower expanded specifically in the Chugoku region because of the availability of low-interest loans developed through the Act on the Promotion of Introducing Electricity into Farming and Fishing Villages (1952). The adoption of the cost principle and total output contracts by the Chugoku Electric Power Company, and the availability of low-cost plants and power generation equipment from local manufacturers (Honda et al., 2017). Shiro Oda, a former board member of the Chugoku Electric Power Company, initiated the movement of community-based small hydropower and played an essential role in gaining support from external actors.

From the late 1940s, electricity demand for food production and industrial development expected to increase, and Japan was experiencing severe power shortages. The existing power plants were not fully operational because of aging and damage caused by aerial attacks during World War II. Moreover, the construction of new large-scale hydropower plants proved difficult, because it is a slow process taking several decades. To rectify this situation, from his experience in managing hydropower plant construction and his enthusiasm to contribute to postwar reconstruction, especially to rural revitalization, Oda proposed a scheme that combined rural electrification with small 
hydropower development. That is, rural communities constructed small hydropower plants and sold the generated electricity to electric power companies. The rural community-led construction of hydropower plants enabled smooth land acquisition, leading to the successful construction of small hydropower plants in less time and for less expense. This meant that rural communities resolved power shortages, increased their agricultural production, and earned revenue from selling electricity. It also allowed electric power companies to increase their power supply without incurring high construction costs. The resolution of the power shortages facilitated a government increase in food production and industry promotion. Oda's proposal was a "win-win-win" for rural communities, electric power companies, and the government. Another unique point of his scheme was that grid-connected hydropower plants sold all the electricity they generated and then purchased the electricity they required. This replaced stand-alone plants for self-consumption, typical for Japanese farmers before World War II. Agricultural electric power demand fluctuated seasonally, so electricity surpluses during the agricultural off-season reduced the profitability of stand-alone plants. To improve plants' business efficiency, he insisted that grid-connected plants were indispensable.

Oda initiated a campaign for community-led small hydropower in the late 1940s. He lobbied the relevant local authorities, electric power companies, and manufacturers of power generation equipment. Simultaneously, he investigated the suitability of sites throughout Japan for hydropower generation and published the results in pamphlets advocating the importance and necessity of community-led construction of small hydropower plants.

For the government, community-led small hydropower was an effective way of solving severe electric power shortages. Hence, the government passed the Act on the Promotion of Introducing Electricity into Farming and Fishing Villages in 1952, allowing JACs to obtain low-interest loans. The Chugoku Electric Power Company had a close relationship with Oda, who was a former board member. Moreover, his proposal had two advantages. First, in the Chugoku region, there were few large rivers and only a limited number of sites suitable for large-scale hydropower. Second, the Chugoku Electric Power Company depended on high-cost, coal-fired power generation more than other electric power companies did. It was also difficult for the company to raise a large amount of money to construct power plants because of excessively high labor costs. His scheme, which enabled the company to increase power supply in less time and with less cost, was therefore beneficial to them. The company, therefore, made a contract with small hydropower owners, based on a cost principle and total-amount purchase system.

While continuing his investigations, Oda visited rural areas and emphasized the importance of farmers constructing small hydropower plants for themselves. Therefore, the farmers consulted him when they wanted to build plants because they lacked hydropower expertise. Furthermore, water wheels and power generators produced by large manufacturing companies headquartered in the Tokyo metropolitan area were expensive. To solve this problem, he established his own company that made water wheels less expensively and consulted on the design of power plants that were specifically suitable to regional sites. He supported the farmers with his company, and concurrently, his company functioned as a business. The company was located in the Chugoku region with easy access to rural areas that was useful when power generation facilities required repairs and maintenance. 
Moreover, in 1952, he organized small hydropower owners into an association, the Chugoku Small Hydropower Association, which conducted collective negotiations with the Chugoku Electric Power Company on the sale price of electricity. This association combatted the difficulty of small hydropower owners, who were small-scale farmers' cooperatives, to negotiate with a giant electric power company that had monopolized regional electric supply.

Therefore, it can be seen that rural communities were unable to construct small hydropower plants without support from the government, electric power companies, and local manufacturers. The business of power generation generally requires large amounts of money and expertise. Negotiating the selling price of electricity with a giant electric power company is also necessary to overcome the regional monopolies of the Japanese energy market. Therefore, money, price negotiations with the Power Company, and engineering expertise made it difficult for rural communities to be involved in the power generation business independently. Shiro Oda played a key role here: not only his social status as a former board member of the electric power company but also his expertise in hydropower businesses led the public and private sectors to support farmers. It is also significant that he started up his own business that produced power plant facilities to help farmers. Although he was not conscious of climate change or the need to reduce $\mathrm{CO}_{2}$ emissions, as there was not much attention on environmental issues at the time, his scheme can be regarded as an example of an eco-economy (Kitchen and Marsden, 2009), i.e., a local development model using renewable energy from which both local communities and businesses benefited. Moreover, Magnani et al., (2017) emphasized the importance of "ecopreneurs," i.e., those who combine business practices with sustainable development, as defined by Gibbs (2009). Hence, Oda can be seen as an "ecopreneur" promoting an eco-economy.

\subsection{Sustainable Management of Community Renewable Energy}

\subsubsection{Japan Agricultural Cooperatives for Electrification (JACEs)}

Local community members to take over the small hydropower business of local JACs when the JACs merged to established JACEs. The JACEs are only engaged in energy production, while JACs, local municipalities, and Land Improvement Districts engage in it as a side business. Hence, JACEs are particularly embodied in community renewable energy and are most similar to green energy cooperatives among community-based small hydropower operators in the region. There are six JACEs in the Chugoku region. Table 1 summarizes the four JACEs located in Tottori Prefecture and the plants they operate. These plants were constructed from 1953 to 1961. Each plant has a conduit-type source with a run-of-river-type operation with a maximum output of 100 to $200 \mathrm{~kW}$. JACEs took over the plant facilities and water rights from the former owners when 14 JACs in the eastern part of the Tottori Prefecture merged as JAC Tottori Inaba in 1995.

Although the JACEs were established for similar reasons, their governing bodies, residents' attitudes towards the plants, and relationships with local communities differ significantly.

Table 1. JACEs and their plants in Tottori Prefecture

\begin{tabular}{lcccc}
\hline The owner (operator) & JACE-A & JACE-B & JACE-C & JACE-D \\
\hline Name of plant & Plant A & Plant B & Plant F & Plant D \\
\hline
\end{tabular}




\begin{tabular}{|c|c|c|c|c|}
\hline Year of construction & 1961 & 1958 & 1954 & 1953 \\
\hline $\begin{array}{l}\text { Owner at the time of } \\
\text { plant construction }\end{array}$ & JAC-A & JAC-B & JAC-F & JAC-G \\
\hline Max. power output & $199 \mathrm{~kW}$ & $175 \mathrm{~kW}$ & $134 \mathrm{~kW}$ & $120 \mathrm{~kW}$ \\
\hline $\begin{array}{l}\text { Year of JACE } \\
\text { establishment }\end{array}$ & 1995 & 1995 & 1995 & 1995 \\
\hline $\begin{array}{l}\text { Number of members } \\
\text { (households) }\end{array}$ & 300 & 118 & 858 & 27 \\
\hline Governing body & $\begin{array}{l}\text { District Council } \\
\text { A }\end{array}$ & $\begin{array}{l}\text { Residents' } \\
\text { Association B }\end{array}$ & $\begin{array}{l}\text { Formerly } \\
\text { JAC-C }\end{array}$ & $\begin{array}{l}\text { None (residents } \\
\text { around District } \\
\text { D) }\end{array}$ \\
\hline $\begin{array}{l}\text { Revenue return to the } \\
\text { local community }\end{array}$ & $\begin{array}{ll}\text { e.g., } & \text { Street } \\
\text { lightning, } & \text { sports } \\
\text { day } & \\
\end{array}$ & $\begin{array}{l}\text { e.g., Assembly hall, } \\
\text { community road }\end{array}$ & None & None \\
\hline
\end{tabular}

The governing bodies of JACE-A and -B are existing local community organizations, the respective geographical territories of which are consistent with those of owners at the time of construction. For example, the operating body of JACE-A is nominally Property Ward A (zaisan-ku) but is, in effect, District Council A (formerly Village A). The governing body of JACE-B is Residents' Association B (once Village B). Therefore, all households in the community, both farm and non-farm, are JACE-A and -B members. JACE-A and -B were established due to the residents' positive evaluation of the plants. The presidents of these JACEs stated: "We did not want to relinquish the property that our community had made" (JACE-A) and "We did not want the merged JAC to retain the plant that our community had developed. We should retain it" (JACE-B). JACE-A and $\mathrm{B}$ returned revenue to the communities when possible, supporting community development directly (e.g., subsidizing streetlight electricity bills) and indirectly (e.g., maintaining an assembly hall and establishing district sports day) related to power generation. While the JACEs do not implement social support activities, they financially support governing bodies and other community social organizations.

In contrast, JACE-C and -D were established as part of the disposal of the former JACs' bad loans or because of soaring maintenance and management expenses. The current geographical ranges of JACE-C and -D are inconsistent with those of the original owners. The governing body of JACE-C is the former JAC-C (formerly Town C) before the merger in 1995, while the original owner was JAC-F, which covered former Village F. JACE-D owned by a few residents living around District $D$, who were relatives and acquaintances of the leader of District $\mathrm{D}$ at the time of plant construction. JACE-C and $\mathrm{D}$ have returned no revenue to their communities because they have not yet been able to earn sufficient income to guard against failure. They have only a distant relationship with the nearby neighborhoods.

\subsubsection{Building Partnerships with External Actors and Local Initiatives: JACE-A}

\subsubsection{History of JACE-A and its Support for the Local Community}

This section analyzes JACE-A to identify the ways in which small hydropower projects have improved rural welfare. JACE-A operates Plant A, which was constructed by JAC-A in District A in 1961. JAC-A merged with two other JACs to become JAC-H 
in 1972, which took possession of the property of JAC-A, including Plant-A. A branch office of JAC-H was opened in District A to manage the plant. When JAC-H began to Discuss a merger with other JACs in the eastern part of Tottori Prefecture; farmers in District A took an interest in it. They felt that they should continue to be involved in the plant's operation and that the rights to operate it locally. Representatives of District A deliberated about how to keep the rights in their community and finally agreed to raise capital and buy the operating rights of the plant. Thus, the farmers invested in the establishment of JACE-A, and bought the operational rights of Plant A and water rights from JAC-H.

Only farmers are eligible to become regular members of a JACE because it is a kind of JAC. Of the 300 households in District A, 280 were farmers, and all became regular members of JACE-A. The remaining 20, who were non-farmers or newcomers, became associate members. In the district, an organization called Property Ward A manages the forests shared by the district's residents. Commissioners of Property Ward A are board members of JACE-A. As shown in Figure 4, District A has eight hamlets, and the number of commissioners of the property ward, in other words, board members of JACE-A, is determined according to the number of households in each hamlet. The annual general meeting of the property ward is held, followed by that of JACE-A, in the same place on the same day. These facts show how the local community manages Plant A as a common resource of District A, like the community-owned forest.

The local community started to operate Plant A in 1995, but initially, the meeting attracted only about 30 participants, including board members, because of low interest. To increase residents' active participation, the president of JACE-A decided to return profits to the community, beginning around 2005, when the plant became profitable. In particular, the electricity bill for street lighting in the district is paid from the profits of the plant. Air conditioners were also installed in the eight hamlets' local community centers. JACE-A also subsidized the cost of installing cable TV by 50,000JPY (475USD) per household in the district, including a few newcomers who had not yet participated in

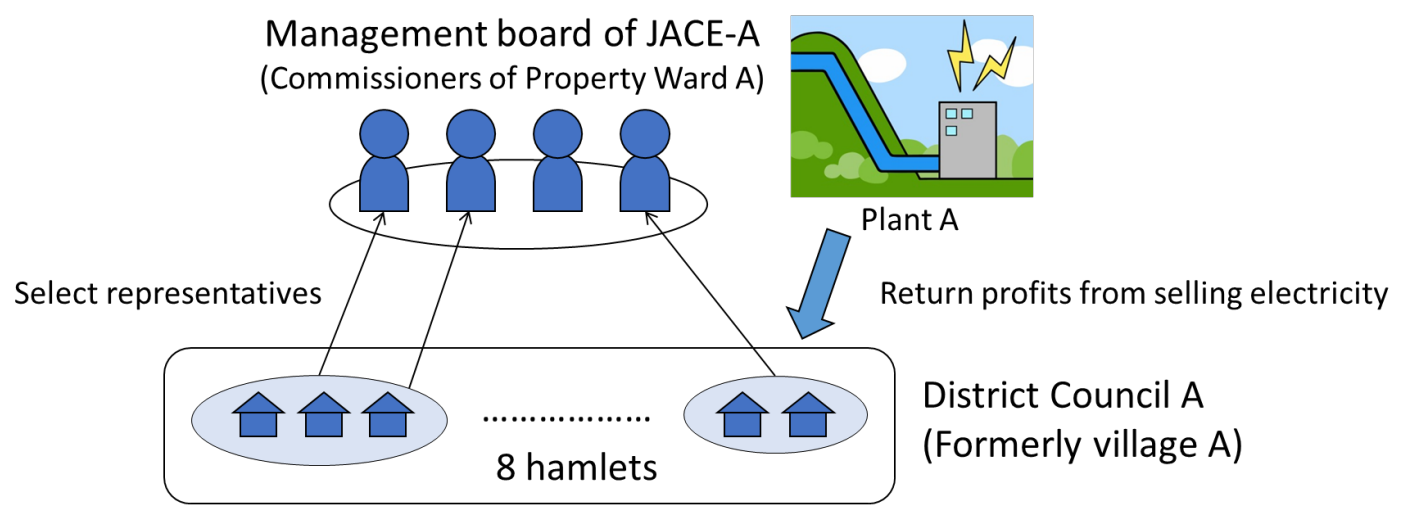

Figure 4. Relationship between District Council A and JACE-A.

JACE-A. In recent years, approximately 500,000JPY (4,750USD) has been spent annually on small gifts for the local sports day in the district in response to a request from residents.

\subsubsection{Collaboration with External Actors in Refurbishing a Small Hydropower Plant}


The great earthquake on March 11, 2011, led to remarkable and rapid changes in electric power policy. For example, the Feed-In Tariff Scheme (FIT), established in 2012, makes it mandatory for electric power companies to buy renewable power electricity at fixed prices set by the government that are much higher than before, for 20 years. The construction of new plants or replacement of old plants requires owners to obtain the authorization of FIT. Following the FIT legislation, most small hydropower business owners in the Chugoku region were authorized to refurbish old plants extensively. However, JACEs had less stable financial bases than JACs, Land Improvement Districts, or local municipalities, because JACEs only engaged in the business of generating electricity. Hence, it was difficult for JACEs to participate in the FIT scheme because raising funds was difficult. Among the four JACEs surveyed, only JACE-B successfully upgraded its plant by itself because the last leader of District B was connected with the local financial sector through his own forestry business. The remaining three had difficulties raising funds and therefore collaborated with companies outside the region to refurbish the plant facilities under the auspices of the TSHA.

JACE-A was the first to complete its refurbishment in April 2018 among the remaining three. Although JACE-A aimed at refurbishing the plant by itself, the cost would have exceeded 200 million JPY. The lending bank asked JACE-A to provide collateral, but the residents' lack of assets dissuaded them from offering any. They eventually collaborated with a gas company in the Tokyo metropolitan area (Company J) to refurbish the plant under TSHA's agency.

Figure 5 shows the relationship between JACE-A, Company J, and other companies

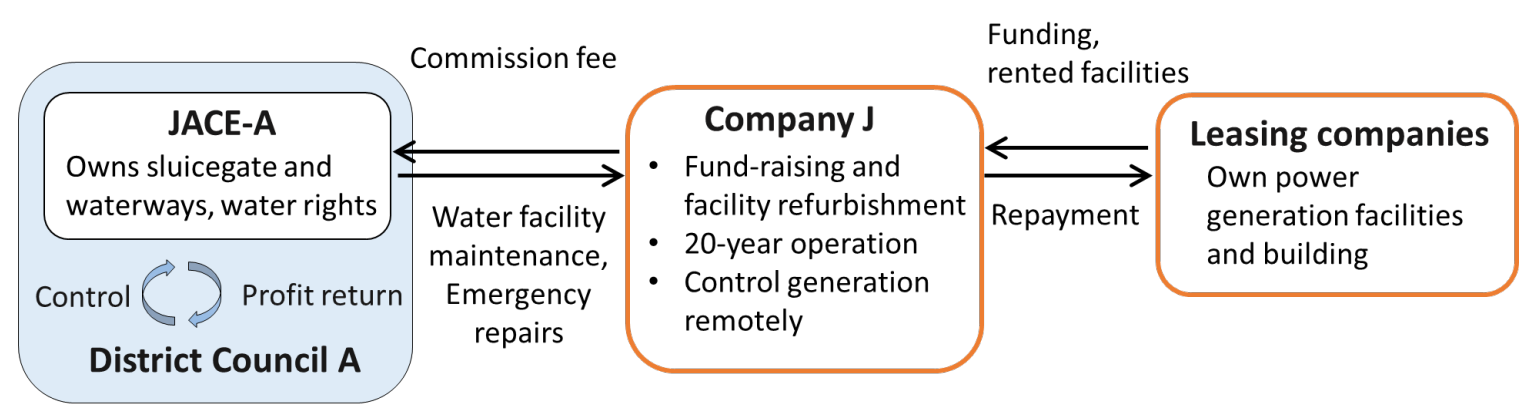

Figure 5. Replacement scheme of JACE-A's small hydropower plant.

Involved in the small hydropower plant scheme. Company J refurbished Plant A and will operate it for the next 20 years (the period during which the electricity generated is bought at the FIT procurement price). Two leasing companies now own the power generators and buildings that is Tottori Prefecture and the other in Tokyo). These leasing companies provide the company with funds and the facilities for plant operation. On the other hand, JACE-A owns the land, water rights, and water facilities such as the water inlet and the headrace, and commissioned by the company to maintain and manage the facilities. Company $\mathbf{J}$ pays a fixed commission fee to JACE-A. The price is set at a level that is sufficient to provide support activities to the local community, which JACE-A had done for some time before the refurbishment, after expenses for repair and other tasks taken out. Company $\mathbf{J}$ controls power generation remotely. In case of a failure, JACE-A conducts emergency procedures. 
The president of JACE-A described the role allocation between Company J and JACEA as, "professionals operate machines, and we manage water use." Power generation facilities require both a qualified Chief Electrical Engineer and a qualified Chief Dam/Waterway Engineer based on the Electricity Business Act. However, it is difficult for residents, especially older residents, in most of the community, to obtain these qualifications. Conversely, managing water use facilities requires knowledge related to aspects of the local area such as climate, terrain, rivers, and disaster management that only long-term residents can bring. Therefore, the president of JACE-A considered that it was appropriate that Company $\mathbf{J}$ should manage hydropower facilities with their expert knowledge. The water use facilities could be overseen by the community with its empirical knowledge, in a relationship that relies on the mutual strengths of all parties involved.

To help Company $\mathbf{J}$ understand the importance of the role of JACE-A, JACE-A persuaded the company managers to work alongside them. For example, the board members and workers of JACE-A must inspect underdrain pipes and four tunnels every four years. The tubes are too narrow to allow people to stand upright, so people have no choice but to crawl on their hands and knees, wearing a helmet with a light to look for tree roots or damage. Furthermore, because mamushi (Japanese pit vipers) may be present, the workers must not touch surfaces with their hands. Such work is difficult and laborious.

Additionally, the work pays only 5,000JPY (47USD) a year plus a fixed daily wage for each community task. The president of JACE-A said that the only reason they did the work was their strong attachment to the community. These joint activities allowed Company $\mathrm{K}$ a better understanding of the importance of JACE-A's activities.

After the FIT was legislated, the TSHA sensed the danger of a situation where hydropower equipment manufacturers operated too many plants properly manage them, which could delay refurbishments and supply of water wheels for two to three years. As the procurement price of renewable energy under the FIT decreased year by year, the longer refurbishments were delayed, the more the procurement price would decrease, reducing the profitability of the refurbishment. Furthermore, because most JACEs in Tottori Prefecture lacked funds and property, they had difficulty raising capital from lenders. Accordingly, TSHA devised a scheme for collaboration between companies that wanted to enter the renewable energy business and small hydropower business owners in Tottori Prefecture, particularly JACEs that had a weak management base and no other revenue sources. As a result, JACEs in Tottori Prefecture were successfully able to refurbish their plants. Furthermore, TSHA not only provided advice to both JACEs and Company J, but also assessed whether the contract was fair for both parties. TSHA provided JACEs with expert advice, including for their FIT applications and validating the estimated cost of the refurbishment, and advised Company $\mathbf{J}$ on how to interact with communities.

The last president of TSHA, who served at around the time of plant refurbishment, regarded water as an invaluable local resource, and strongly feels that, "There was nothing more regrettable than transferring a plant to an outsider for refurbishment because the plant was established and maintained by locals with great effort." In the context of overconcentration of wealth in Tokyo, the money saved by using a local resource (arguably a local treasure), was flowing to business operators outside Tottori Prefecture, causing distress to the local community. "Although earning profits makes 
sense, profits must be fair" (former president of TSHA). From this perspective, TSHA not only provided advice to operating companies but also monitored their activities.

\subsection{Summary Discussion}

The results of these case studies can be summarized as follows. First, the communitybased hydropower business has a fragile management base. Refurbishment of a small hydropower plant with a capacity of a few hundred kilowatts requires a considerable amount of money. Further, verifying the estimated cost and operating the plant requires expert knowledge. These aspects mean that local communities experienced the same difficulties in recent years as they were facing in the 1950s and 1960s.

Second, this is precisely why partnerships with external actors, especially businesses in urban areas, are indispensable for local communities to keep their plant business going. Therefore, it stressed that most JACEs surveyed had to abandon their attempts to raise finance by themselves and collaborated with not only local businesses (as communities had done in the early stages) but also urban businesses to refurbish their plants. The situation in the 1950s and 1960s and that of recent years differ at this point, which is due to the weakened communities and depressed economies in rural areas after the 1990s. Population decline and aging in rural areas make it more difficult for a community to find funds, technologies, and human resources, all of which are indispensable for plant operation, within the community than it was in the early stages. The local economy also exhausted by the globalization of the Japanese economy after the 1990s. Hence, it can be seen that rural communities forced to establish collaborations with urban businesses.

Furthermore, the results indicate that as partnerships with local or urban businesses are likely to be needed, it is vital to develop a business-minded framework in which both communities and their partners can profit through the introduction of small hydropower businesses. Thus, it seems that a co-development model based on collaboration between rural and urban areas will become more necessary for the development of community renewable energy in the future. The case of JACE-A is an excellent example of such a model. Third, when collaborating with external actors, communities must find the selfmotivation to maintain their independence. There are wide gaps in financial power and expert knowledge between communities and external actors, mainly operating companies, which gives external actors an advantage in negotiations. The key factors in JACE-A's success were that TSHA advised both JACE-A and Company J evenhandedly. Hence, this case study suggests that a third party with expert knowledge and the ability to audit processes could play a key role in establishing community independence from external actors.

\section{Conclusion}

This study examined the ability of rural communities to construct and manage small hydropower plants in the 1950s and 1960s and recent years. Local communities have always been unable effectively to operate small hydropower without technical, financial, and political support from local or urban companies in the power generation industry. Therefore, the development of community renewable energy requires a business-minded framework in which both the communities and businesses can financially benefit from small hydropower projects. Furthermore, when communities build partnerships with companies, a third party with expert knowledge acting on behalf of the community can 
play a crucial role in maintaining the community's independence. This may be because of the characteristics of the power generation business itself, along with the features of the Japanese electricity market. Power generation businesses require high levels of expertise and large capital. In the Japanese electricity market, prices must be negotiated with giant electric power companies. Hence, communities have no choice but to collaborate with companies and allow them some control of their small hydropower businesses. Due to the deregulation of retail electricity sales from 2016 in Japan, some new businesses called "Power Producers and Suppliers," consumers' cooperatives, and local municipalities have started their own power generation and/or supply operations. Hence, further studies are needed to determine the effects of this new movement in the energy market on community renewable energy projects in the future.

\section{Acknowledgment}

This paper was based on a presentation at the 6th International Conference of Asian Rural Sociology Association in August 2018 in Makassar, Indonesia, and the 83rd Annual Meeting of the Rural Sociological Society in August 2020 in Richmond, United States. The author would like to thank Dr. T. Matsuoka, Dr. K. Iwamoto, and Dr. T. Miura for their collaboration in the early stages of this work. The author also appreciated the valuable comments of Dr. Y. Kawamura and Dr. K. Sakamoto. JSPS KAKENHI Grant Numbers JP16K21182 and JP19K20506 supported this work. It was partly funded by the Consumer Co-operative Institute of Japan, Nippon Life Insurance Foundation, and the Sanyo Broadcasting Foundation. Neither the collaborators nor the foundations bear any responsibility for the analyses or interpretations presented here.

\section{References}

Agency for Natural Resources and Energy. 2012. List of Certified Hydropower Plants by Special Measures Law Concerning the Use of New Energy by Electric Utilities (Certificated by March 31, 2012). https://www.rps.go.jp/RPS/newcontents/top/joholink-kiroku.html, Accessed on 5 October 2020. (in Japanese)

Ahlborg, H. and Sjöstedt, M. 2015. Small-Scale Hydropower in Africa: Socio-Technical Designs for Renewable Energy in Tanzanian Villages. Energy Research and Social Science, 5: 20-33.

Bracken, L. J., Bulkeley, H. A. and Maynard, C. M. 2014. Micro-Hydro Power in the UK: The Role of Communities in an Emerging Energy Resource. Energy Policy, 68: 92-101.

Brummer, V. 2018. Community Energy-Benefits and Barriers: A Comparative Literature Review of Community Energy in the UK, Germany, and the USA, the Benefits It Provides for Society, and the Barriers It Faces. Renewable and Sustainable Energy Review, 94: 187-196.

Fabusoro, E, Maruyama, M., Fapojuwo, O. E., 2012. Japanese Farmers' Dilemma on ProLiberalization Policies and Structural Transformation of the Japan Agricultural Cooperative. Proceeding of IFSA (International Farming Systems Association Europe Group). http://ifsa.boku.ac.at/cms/fileadmin/Proceeding2012/IFSA2012_WS2.1_Fabusoro .pdf, Accessed on 17 November 2020. 
Gibbs, D. 2009. Sustainability Entrepreneurs, Ecopreneurs, and the Development of a Sustainable Economy. Greener Management International, 55: 63-78.

Hinshelwood, E. 2001. Power to the People: Community-Led Wind Energy Obstacles and Opportunities in a South Wales Valley. Community Development Journal, 36: 95-110.

Honda, Y., Matsuoka, T. and Iwamoto, K. 2017. Stakeholders' Role in Small-Scale Hydropower Development by Japan Agricultural Cooperatives in the Chugoku Region. Journal of Systematic Regional Geography, 23(1): 18-33. (in Japanese)

Kaphengst, T. and Velten, E. K. 2014. Energy Transition and Behavioral Change in Rural Areas: The Role of Energy Cooperatives. WWW for Europe Working Paper 60. https://www.ecologic.eu/sites/files/publication/2014/kaphengst-velten-2014energy-transition-and-behavioual-change-in-rural-areas-the-role-of-energycooperatives.pdf, Accessed on 19 September 2020.

Kitchen, L. and Marsden, T. K. 2009. Creating Sustainable Rural Development Through Stimulating the Eco-Economy: Beyond the Eco-Economic Paradox? Sociologia Ruralis, 49(3): 273-294.

Kuramochi, T. 2015. Review of Energy and Climate Policy Developments in Japan Before and After Fukushima. Renewable and Sustainable Energy Reviews, 43: 1320-1332.

Magnani, N., Maretti, M., Salvatore, R. and Scotti, I. 2017. Ecopreneurs, Rural Development, and Alternative Socio-Technical Arrangements for Community Renewable Energy. Journal of Rural Studies, 52: 33-41.

Mizuno, E. 2014. Overview of Wind Energy Policy and Development in Japan. Renewable and Sustainable Energy Reviews, 40: 999-1018.

National Federation of Agricultural Cooperative Associations. 2019. ZEN-NOH Report 2019. https://www.zennoh.or.jp/english/book/report/2019.pdf, Accessed on 17 November 2020.

Paish, O. 2002. Small Hydro Power: Technology and Current Status. Renewable and Sustainable Energy Reviews, 6(6): 537-556.

Reddy, V. R., Uitto, J. I., Frans, D. R. and Matin, N. 2006. Achieving Global Environmental Benefits Through Local Development of Clean Energy? The Case of Small Hilly Hydel in India. Energy Policy, 34(18): 4069-4080.

Sarker, A. 2012. Federated Rural Organization for Governing the Commons in Japan. Journal of Rural Studies, 36: 42-51.

Schreuer, A. and Weismeier-Sammer, D. 2010. Energy Cooperatives and Local Ownership in the Field of Renewable Energy Technologies: A Literature Review. Research Reports / RICC 4. WU Vienna University of Economics and Business, Vienna.

Walker, G. and Devine-Wright, P. 2008. Community Renewable Energy: What Should It Mean? Energy Policy, 36(2): 497-500.

Walker, G., Hunter, S., Devine-Wright, P., Evans, B. and Fay, H. 2007. Harnessing Community Energies: Explaining and Evaluating Community-Based Localism in Renewable Energy Policy in the UK. Global Environmental Politics, 7(2): 64-82. 